\title{
Carcinoma of the Eyelid pNO TNM Finding v7
}

National Cancer Institute

\section{Source}

National Cancer Institute. Carcinoma of the Eyelid pNO TNM Finding v7. NCI Thesaurus. Code C88571.

Carcinoma of the eyelid with no regional lymph node metastasis, based upon lymph node biopsy. (from AJCC 7th Ed.) 